\title{
Psychosemantic Peculiarities of Promotional Videos Perception*
}

\section{Психосемантичні особливості сприйняття рекламних відеороликів **}

Anzhelika Shamne ${ }^{1}$

Dr. in Psychology, Associate

Professor

\author{
Анжеліка Шамне ${ }^{1}$ \\ доктор психологічних наук, \\ доцент
}

\author{
E-mail: shamne@ukr.net \\ orcid.org/0000-0003-1541-6079
}

\section{Tamiliia Dotsevych ${ }^{2}$}

Dr. in Psychology, Associate

Professor

\section{Тамілія Доцевич ${ }^{2}$}

доктор психологічних наук, доцент

\section{E-mail: tamiliia.dotsevych@gmail.com orcid.org/0000-0001-6424-7801}

\section{Alina Akimova ${ }^{3}$}

Ph.D. in Philology, Assistant

Professor

\section{Аліна Акімова ${ }^{3}$}

кандидат філологічних наук, доцент

E-mail: a alina09@ukr.net orcid.org/0000-0001-7546-2902

ResearcherID C-5824-2017

${ }^{1}$ National University of Life and Environmental Sciences of Ukraine, Department of Psychology 10, Heroyiv Oborony Str., Kyiv, Ukraine, 03041
${ }^{1}$ Національний університет біоресурсів і природокористування України, кафедра психології $\triangle$ вул. Героїв оборони, 10, м. Київ, Україна, 03041

* This study is done within the framework of the State project and finance support of the Ministry of Education and Science of Ukraine (Registration number 0119U100726).

** Дослідження виконане в рамках Держбюджетного проекту за фінансової підтримки Міністерства освіти і науки України (Реєстраційний номер 0119U100726). 
${ }^{2}$ Pereiaslav-Khmelnytskyi

Hryhorii Skovoroda State

Pedagogical University

30, Sukhomlynskyi Str., Pereiaslav-Khmelnytskyi, Kyiv Reg., Ukraine, 08401

${ }^{3}$ Interregional Academy of

Personnel Management

2, Frometivska Str., Kyiv, Ukraine, 203039
${ }^{2} Д В Н 3$ «Переяслав-

Хмельницький державний педагогічний університет імені Григорія Сковороди» $\triangle$ вул. Сухомлинського, 30, м. Переяслав-Хмельницький, Київська обл., Україна, 08401

\author{
${ }^{3}$ Міжрегіональна Академія \\ управління персоналом, \\ вул. Фрометівська, 2, м. Київ, \\ Україна, 203039
}

Original manuscript received August 14, 2018

Revised manuscript accepted March 03, 2019

\section{ABSTRACT}

The article presents the findings of a study of the psycho-semantic characteristics of the perception of promotional videos in the juvenile and adolescent age periods (as exemplified by the students of a lyceum and those of an institution of higher education in Ukraine). The modern advertising is seen as a societal and sociopsychological phenomenon that models not only the behavior but also the values, standards and mindsets of the younger generation. The scientific principles of the experimental psycho-semantics became the methodological basis for the empirical research in question. The purpose of the research was to reconstruct semantic spaces and an individual system of meanings, through the prism of which advertisements are perceived by juveniles and adolescents of both genders.

The psycho-semantic research was carried out in three stages: scaling of advertising objects (on the basis of the semantic differential method), the construction of semantic spaces of promotional videos and the interpretation of the results obtained. Five promotional videos of different types were selected as the evaluation objects (an "Otrivin" animation video with computer graphics and special effects; a "Pantene» actor-supported voice-over music video; a "Hylak Forte» voice-over information-type video; a "Samsung» celebrity figure-supported video; a "Raiffeisenbank» storyline actor-supported voice-over music video). A comparative analysis of the psycho-semantic spaces of the above-mentioned objects was performed; the age and gender characteristics of their perception in the juvenile and adolescent age periods were determined.

The following factors were identified as the main semantic axes of the psychosemantic perception (as exemplified by the "Raiffeisenbank» promotional video): "Confidence in (distrust of) advertising» (SD indicators "true - false», «informative less informative», «intelligent - stupid»); "Emotional attractiveness (unattractiveness) 
of advertising» (SD indicators "attractive - repulsive», "joyful - sad»; "Tactfulness (obtrusiveness) of advertising» (SD indicators "relaxed - tense», "modest - obtrusive», «interesting - boring»).

Key words: semantic differential method, psychology of advertising, promotional video, juvenile age, adolescent age, gender differences.

\section{Вступ}

В сучасному інформаційному просторі реклама як вид комунікації пов’язана не лише з комерційними інтересами, але і 3 моделюванням поведінки, цінностей, настанов та світосприймання сучасної молоді. Будучи спресованим образом сучасності, в якому акумулюються почуття і досвід усього суспільства, вона постійно поновлюється, пропонуючи споживачеві готові ідеї, персонажі, стереотипи, іміджі, за зразками яких людина будує «нові» форми життєдіяльності (Зирка, 2004). У такий спосіб сучасна реклама тиражує певний світогляд, формує певний тип особистості (Музыкант, 2002).

У психолінгвістиці сприймання рекламного тексту розглядається як процес співвіднесення людиною вилученого 3 нього змісту із своїм соціальним досвідом (Тарасов, 1974: 95). В мотиві (товарі, що рекламується) опредмечується усвідомлення незадоволеної потреби людини (Попова, 2005; Тарасов, 1974), яка скеровує іiі поведінку. Тож, характер оцінного ставлення до рекламного повідомлення та особливості його сприйняття людиною

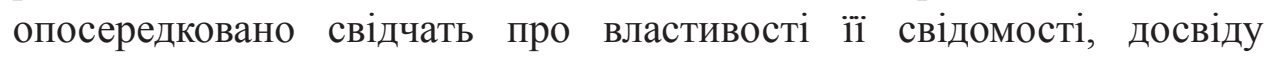
та ціннісно-мотиваційної сфери. Тому актуальним є дослідження взаємозв’язку афективно забарвленого значення реклами та їі семантичної організації в індивідуальній свідомості з урахуванням специфіки як самої реклами, так і психологічних, вікових та гендерних особливостей іï споживачів.

Основу вивчення реклами як комунікаційного, соціопсихологічного, культурного явища становлять соціологічні та психологічні дослідження масових комунікацій (Музыкант, 2002; Ученова, 2006; Шмига, 2006). Рекламний текст є концептуальним складником рекламного дискурсу (Заболотна, 2009; Зирка, 2004, 
Тарасов, 1974; Дедюхин, 2006; Попова, 2005). 3 точки зору комунікаційної ефективності його розглядають як явище семіотичне, що означає «зв'язані знакові комплекси» (Бахтин, 1979: 281), які створюються на основі синтезу між вербальними та невербальними (звукоряд, відеоряд, звучання тощо) засобами (Корнилова \& Гордеев, 2001: 79).

У сучасному комунікативно-інформаційному просторі ефективність реклами залежить, з одного боку, від адекватного поєднання активованих нею репрезентативних систем, а 3 іншого від органічного синтезу впливів, адресованих як когнітивним процесам переробки інформації, так і афективному ставленню людини до рекламного повідомлення, іiї сенсам, цінностям, емоціям та почуттям. Тож, вихідним для нашого дослідження є розуміння реклами як складного комплексу когнітивно-комунікативних, емоційно-чуттєвих, ціннісно-нормативних компонентів, об'єднаних в ієрархічну структуру та спрямованих на формування попиту, реалізацію товарів і послуг, а також ідей і певних концепцій життя (Шмига, 2014: 30).

Сучасна реклама як феномен і ментальності, і людської психіки виявляється настільки багатогранною, динамічною i схильною до трансформації у часі, що вивчення iï сутнісних характеристик навряд чи можна вважати закінченим. 3 поширенням новітніх комп'ютерних технологій та появою у XXI ст. нового «цифрового» покоління все більш впливовим різновидом сучасної реклами стають рекламні відеоролики як мультимедійний дискурс. Широко представлені як на телебаченні, так і в мережі Інтернет, вони стають новою комунікативною формою, яка є конгломератом вербальних, візуальних і аудіовізуальних компонентів. Слід зазначити, що попри значну кількість праць, присвячених дослідженню лінгвістичних та психолінгвістичних аспектів функціонування рекламного тексту (Войтенко, 2017; Дедюхин, 2006; Заболотна, 2009; Залевская, 2014; Зирка, 2004; Лившиц, 1999; Тарасов, 1974; Шмига, 2006; Хавкіна, 2010), особливості сприймання сучасною молоддю рекламних відеороликів як різновиду полікодового рекламного повідомлення ще не були об'єктом психосемантичного анализу.

Рекламний відеоролик вважається одним 3 найбільш ефективних видів сучасної реклами, оскільки він конституюється усім спектром засобів вираження кіно: кадр, монтаж, музичний 
супровід, шумові ефекти, крупний, далекий та панорамний плани, темп, міміка і жести, мовлення персонажів i/або диктора та ін. Він органічно поєднує вербальні (текст) і невербальні (зображення, звуковий та музичний вміст тощо) компоненти, зокрема, візуальнографічні (колір, образотворчі елементи, просторово-композиційне рішення тощо), аудіальні (різні засоби звукового дизайну, інтонація, ритм та ін.), кінетичні (жести, поза, міміка).

Сутнісними ознаками цього різновиду комунікації є поєднання ознак статичної та динамічної реклами, мовного та немовного компонентів і створення інтерактивних рекламних блоків, що надає можливість зв'язувати в осмислене ціле вербальний, візуальний та аудіовізуальний текст. Основне смислове і знакове навантаження у рекламних відеороликах базується на ситуації, представленій у відеоряді, що містить іконічну складову і супроводжується емоційно забарвленою тональністю і яскраво вираженими семантикою та символізмом, які апелюють до сучасних цінностей, привабливих моделей поведінки.

Враховуючи все вищесказане предметом дослідження $\epsilon$ психосемантичні особливості сприймання та оцінювання рекламних відеороликів юнаками та дівчатами підліткового та юнацького віку. Мета дослідження полягає у визначені структури психосемантичного простору значень та психосемантичних особливостей сприймання комерційних рекламних відеороликів в підлітковому та юнацькому віці. Мета дослідження зумовила виконання таких завдань: розглянути особливості оцінювання рекламних відеороликів методом семантичного диференціала; здійснити реконструкцію семантичних просторів їх змісту в контексті вікових та гендерних характеристик досліджуваних, визначити особливості психосемантичної структури найбільш емоційно привабливого для сучасної молоді рекламного відеоролика.

Дослідження психосемантичних особливостей сприймання рекламних відеороликів у період дорослішання дозволить більш чітко визначити специфіку індивідуальної системи значень, через призму якої відбувається їх сприймання молоддю різного віку та статі. Це також сприятиме глибшому розумінню психолінгвістичних закономірностей семантичної переробки та сприйняття аудіовізуальної інформації людиною. 
Виходячи 3 мети та завдань дослідження, вихідним теоретичним положенням роботи є нерозривна єдність раціонального мислення, перцепції, емоцій, почуттів i волі в забезпеченні розумової та перцептивної діяльності людини як споживача реклами, на якій акцентують увагу представники сучасної когнітивної науки (Di Paolo \& Thompson, 2014; Panksepp, 2000; Sheets-Johnstone, 2012; Trevarthen \& Frank, 2012 та ін.); лінгвістики та психолінгвістики (Залевская, 2014; Vorobyova, 2017; Zlatev, 2016; Foolen, 2012).

\section{Методи і методики дослідження}

Методичною основою психосемантичного дослідження стали праці (Osgood, 1984; Osgood, Miron \& May, 1975), які продукували методику семантичного диференціала; експериментальна психосемантика В.Ф. Петренка (Петренко, 2005) та О.Г. Шмельова (Шмелёв, 2002). У зарубіжній психосемантиці метод семантичного диференціала на основі біполярних конструктів використовується для вимірювання конотативного значення об'єктів та інваріантних категоріальних структур суб'єктивного досвіду людини (Осгуд, Суси \& Танненбаум, 1972; Osgood, 1984). Доцільність його використання для оцінки рекламної продукції доведена в працях багатьох психологів, маркетологів та рекламістів (Петренко, 2005: 23; Plichtová, 2002: 81; Urbánek, 2003: 22).

Емпіричне дослідження здійснювалося протягом жовтнялистопада 2017 року на базі загальноосвітнього навчального закладу «Криворізький науково-технічний металургійний ліцей № 16» у 10-11-х класах (чисельність вибірки - 47 досліджуваних) та на базі Національного університету біоресурсів та природокористування України серед студентів 3-го курсу гуманітарно-педагогічного факультету (чисельність вибірки - 49 досліджуваних). Загальна чисельність вибірки - 96 досліджуваних віком від 15 до 21 року (47 дівчат та 49 юнаків).

В експертному оцінюванні рекламних відеороликів взяли участь 5 кваліфікованих експертів (3 експерти-психологи та 2 фахівці-практики 3 реклами). 3 метою первинної селекції вони розподілили 30 запропонованих нами відеороликів минулих 
років (2012-2014), які зберігаються на сайті YouTube, на п’ять типів (Лебедев-Любимов, 2003: 206). Їх подальше оцінювання здійснювалося ними за 5-бальною шкалою на основі критеріїв: зрозумілість, емоційна позитивність, інформативність, довіра, запам`ятовуваність, спонукання до дії. Результати оцінок усереднювалися для кожного відеоролика (оцінки знаходилися в інтервалі 2,9-4,7). Для визначення узгодженості думок експертів відносно рангів рекламних роликів ми застосували коефіцієнт конкордації Кендалла (статистичний програмний засіб «AtteStat»). Коефіцієнт узгодженості думок експертів W виявився значущим $(\mathrm{W} \geq 0,76)$. Отже, для дослідження було обрано п'ять рекламних відеороликів різних типів:

1) мультиплікаційний ролик «Отривін» на основі комп’ютерної графіки та спецефектів (2D i 3D графіка), який рекламує засіб від нежитю, його герої - «анімаційні носи» (https://www.youtube.com/ watch? $=4 x \cot F b \operatorname{KIj} 8)$;

2) музичний ролик «Пантін» 3 участю акторів та 3 закадровим мовним супроводом (постановочний сценарій); рекламний сюжет - красива жінка, успіх якої пов'язаний з використанням засобу «Pantene Pro-V» та наслідком цього - доглянутим волоссям (https://www.youtube.com/watch?v=T8zMvfbp7Wk);

3) музичний відеоролик інформаційного типу «Хілакфорте» без участі акторів, 3 закадровим мовним супроводом та 3 елементами анімації у вигляді прямого звернення до глядачів, який надає інформацію про рекламований лікарський засіб (https://www. youtube.com/watch?v=bgd4td-_TVQ);

4) рекламний відеоролик «Samsung», побудований на основі використання постаті відомої особистості; рекламний сюжет - зірка великого тенісу М. Шарапова, яка у вишуканій сукні імітує рухи тенісистки, рекламуючи новий мобільний телефон «Samsung GALAXY LaFleur» (https://www.youtube.com/ watch? $=$ YvBAQM1 InKE);

5) сюжетний музичний відеоролик «Банк Райфайзен» (слоган «Потрібен тим, хто потрібен») з акторами та закадровим дикторським текстом, побудований на основі відео-історій та мікро-діалогів між акторами (https://www.youtube.com/watch?v=JQgMt19Se60).

Досліджувані дивилися блок відеороликів протягом однієї години (кожен - по два рази) і оцінювали їх за допомогою методики 
семантичного диференціала Ч. Осгуда. В якості показників було використано шкали - критерії оцінки реклами (загальною кількістю - 13), запропоновані у роботі О.М. Лебедєва-Любимова (Лебедев-Любимов, 2003) (табл. 1).

Таблиця 1. Критерії оцінки реклами (за методикою семантичного диференціала Ч. Осгуда)

\begin{tabular}{lrr}
\hline Критерії оцінки & \multicolumn{1}{c}{ Шкали } & Критерії оцінки \\
\hline Розслаблений & $-3-2-1$ & $0+1+2+3$ \\
Скромний & $-3-2-10+1+2+3$ & Напружений \\
Зрозумілий & $-3-2-10+1+2+3$ & Нав'язливий \\
Цікавий & $-3-2-10+1+2+3$ & Незрозумілий \\
Радісний & $-3-2-10+1+2+3$ & Нудний \\
Інформативний & $-3-2-10+1+2+3$ & Сумний \\
Швидкий & $-3-2-10+1+2+3$ & Налоінформативний \\
Оригінальний & $-3-2-10+1+2+3$ & Повільний \\
Розумний & $-3-2-10+1+2+3$ & Банальний \\
Неагресивний & $-3-2-10+1+2+3$ & Нерозумний \\
Красивий & $-3-2-10+1+2+3$ & Агресивний \\
Привабливий & $-3-2-10+1+2+3$ & Некрасивий \\
Правдивий & $-3-2-10+1+2+3$ & Відштовхуючий \\
\hline
\end{tabular}

Отже, у психосемантичному експерименті ми послідовно співставляли п'ять рекламних відеороликів 3 тезаурусом ознак СД (за допомогою біполярних вербальних шкал); встановлювали міру семантичної подібності (на основі подібності оцінок за шкалами); потім на основі факторного аналізу групували шкали в категоріїфактори і будували семантичний простір зазначених відеороликів як досліджуваної реальності.

На першому етапі ми порівнювали оцінки респондентів 1516 років (учні ліцею) та 19-21 року (студенти 3ВО), а на другому оцінки тих самих респондентів, але на основі гендерного розподілу, тобто оцінки дівчат та юнаків у віці 15-21 років. На основі середніх значень за шкалами СД ми побудували графіки психосемантичної оцінки п'яти рекламних роликів у двох вікових групах (рис. 1, 2) та двох гендерних групах (рис. 3, 4). 


\section{Результати та дискусії}

Згідно графіку семантичних оцінок учнів підліткового віку високі позитивні оцінки отримали рекламні відеоролики з участю акторів («Пантін» та «Банк Райфайзен») (рис. 1).

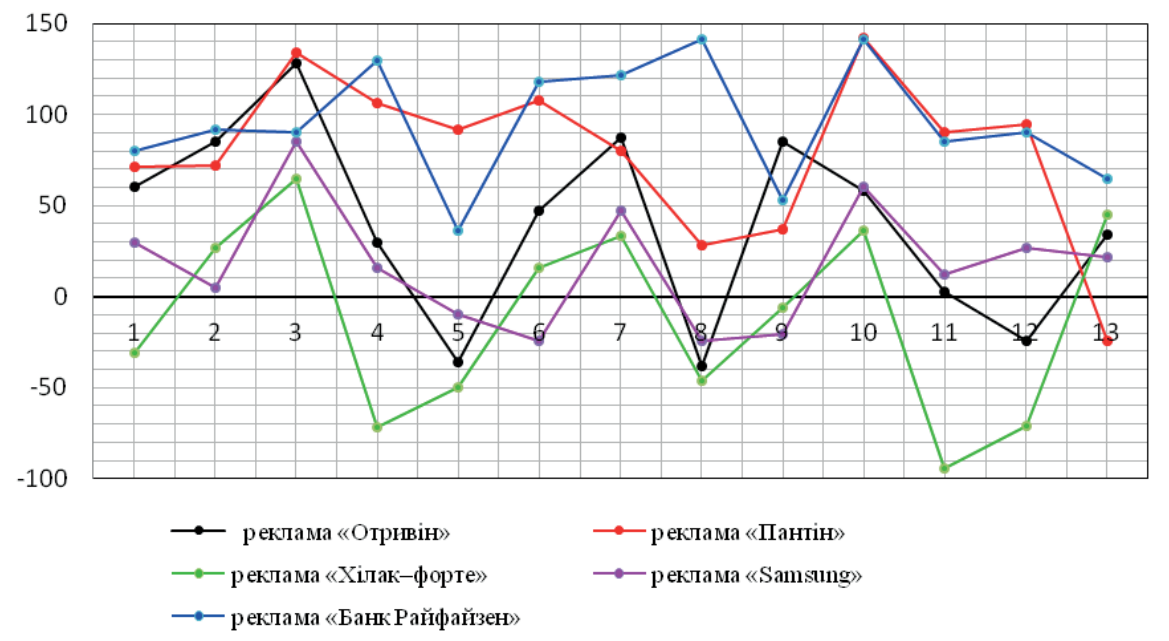

Рис. 1. Профілі середньогрупових оцінок відеороликів за методикою біполярний СД респондентів підліткового віку

Ïх семантичний простір складають такі ознаки як «привабливий», «цікавий», «оригінальний», «зрозумілий», «інформативний». Однак, відеоролик «Пантін» отримав низькі показники за шкалою «правдивість рекламного ролику», а «Пантін» та «Банк Райфайзен» оцінені як «агресивні». Ролик 3 використанням комп’ютерних спецефектів («Отривін») є «швидким», «зрозумілим», але «нерозумним».

Семантичний простір відеоролика «Хілак-форте» будується переважно на негативних характеристиках («нудний», «сумний», «некрасивий» і «відштовхуючий»). Найбільш суперечливою в оцінках підлітків $\epsilon$ семантика відеоролика «Samsung», який, з одного боку, охарактеризовано як «малоінформативний», «банальний» i «нерозумний», а 3 іншого - як «зрозумілий», «швидкий», «неагресивний».

Респонденти юнацького віку (студенти) також позитивно оцінили рекламні ролики «Пантін» та «Банк Райфайзен» (рис. 2). 
Ïх семантичний простір склали як позитивні («привабливий», «цікавий», «оригінальний», «зрозумілий», «інформативний») так i негативні («агресивний») характеристики.

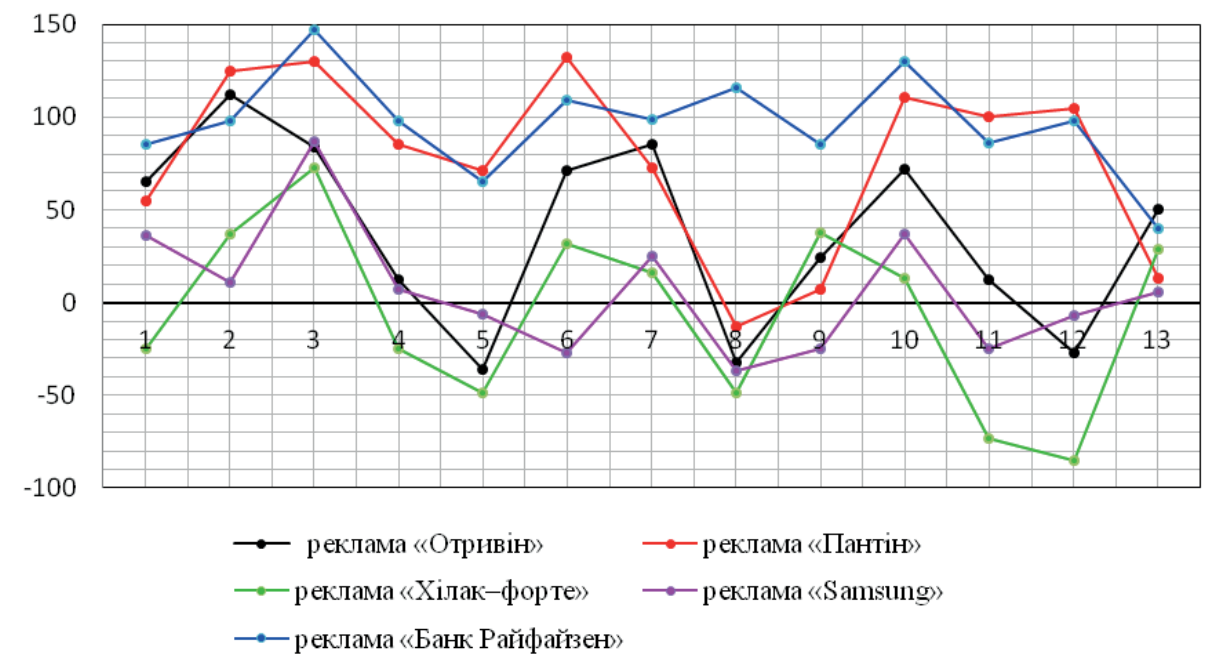

Рис. 2. Профілі середньогрупових очінок відеороликів за методикою біполярний СД респондентів юнацького віку

Відеоролик «Отривін», побудований на комп'ютерних спецефектах, оцінено студентами як «інформативний», «скромний», «швидкий» та «агресивний». Як «зрозумілий», але, водночас «банальний» сприймається студентами рекламний ролик «Samsung» 3 участю знаменитості. Переважно негативні оцінки отримав рекламний ролик без участі акторів та комп'ютерних спецефектів «Хілак-форте». Він $\epsilon$ «зрозумілим», але «сумним», «банальним», «некрасивим» та «відштовхуючим».

Отже, існують певні якісні особливості структури семантичного простору змісту реклами в залежності від вікових особливостей. Наприклад, відеоролик «Хілак-форте» у учнів (порівняно із студентами) отримав більш широкий перелік негативних оцінок, а ролик «Samsung» - позитивних. Те, що в рекламі «Хілак-форте» домінує інформативна функція за рахунок детального опису характеристик товару, послаблює емотивну i, відповідно, переконувальну функції цієї реклами як для підлітків, так і для юнаків. 
Респонденти обох вікових груп нейтрально або негативно оцінюють відеоролик 3 участю всесвітньо відомої тенісистки М. Шарапової. Використання у рекламі знаменитостей є однією із стратегій маркетингових комунікацій (Erdogan, 1999: 291), яка не завжди призводить до очікуваних результатів, що було показано, наприклад, в дослідженні використання соціальної реклами з участю зірок (Spalova \& Bacikova, 2017). Апостеріорний комунікативний смисл відеоролика виформовується в процесі вичитування адресатом підтексту повідомлення (Войтенко, 2017: 6). Це образ сильної, незалежної, самовпевненої жінки, яка при цьому не втрачає своєї краси та жіночності; багато дівчат мріяли б бути схожими на неї; здійснити це бажання їм може допомогти неперевершений телефон бренду «Samsung».

Якісний аналіз даних дозволяє припускати, що оцінки за шкалою «правдивий - неправдивий» певною мірою пов'язані 3 загальним емоційним сприйняттям рекламного ролику. Тенденція полягає у тому, що в обох вікових групах як більш правдиві оцінюються більш емоційно привабливі ролики. Однак, це припущення потребує додатковою перевірки.

Гендерні особливості виявилися більш яскравими. Як показали результати, якісні показники сприйняття та оцінювання реклами у юнаків та дівчат суттєво відрізняються. Майже за всіма показниками юнаки (рис. 3) найбільш позитивно оцінюють рекламу «Банк Райфайзен». Також наповненим позитивними ознаками $€$ семантичний простір рекламних роликів «Отривін» (крім ознаки «сумний») та «Пантін».

Найбільш негативно юнаками був сприйнятий рекламний ролик «Хілак-форте» (крім показників «скромний» та «зрозумілий»). Юнаки доволі критично оцінили ролик «Samsung», визначаючи його як «зрозумілий», але «малоінформативний», «банальний», «нерозумний», «відштовхуючий» та «неправдивий». Отже, факт того, що юнаки сприймають знаменитостей протилежної статі як більш привабливих, ніж знаменитостей своєї статі (Phua, Lin \& Lim, 2018), не підтвердився. Можна погодитися 3 тим, що емпіричні висновки щодо ефекту гендерної взаємодії між знаменитостями та цільовими аудиторіями $є$ неоднозначними (Greene \& AdamsPrice, 1990). В цій гендерній групі відмічається низький показник 
по шкалі «правдивий - неправдивий» за всіма відеороликами (крім «Банк Райфайзен»).



Рис. 3. Профілі середньогрупових оцінок відеороликів за методикою біполярний СД респондентів чоловічої статі

Серед дівчат (рис. 4) високі позитивні оцінки за всіма характеристиками також отримали ролики «Банк Райфайзен» та «Пантін» (хоча він одночасно є також «банальним», «нерозумним»).



Рис. 4. Профілі середньогрупових оцінок відеороликів за методикою біполярний СД респондентів жіночої статі 
Відеоролик «Отривін» був сприйнятий дівчатами значно менш позитивно, ніж юнаками, і отримав більше негативних оцінок («сумний», «банальний», «некрасивий», «відштовхуючий»). Дівчата менш критично оцінили ролик «Samsung» («зрозумілий», «швидкий» та «неагресивний»). Як «нудний», «банальний», «нерозумний», «агресивний», «некрасивий», «відштовхуючий» був оцінений рекламний ролик «Хілак-форте». На відміну від юнаків, за шкалою «правдивість» рекламного ролику дівчата позитивно оцінюють рекламу «Пантін» та «Банк Райфайзен».

Отже, найбільш високі позитивні оцінки в обох гендерних групах отримали ігрові рекламні відеоролики за участю акторів («Пантін», «Банк Райфайзен»). Найбільше відхилення від «ідеального» отримав інформаційний рекламний відеоролик «Хілакфорте». Юнаки більш позитивно сприймають рекламні відеоролики 3 використанням комп'ютерної графіки та спецефектів («Отривін»), а дівчата - відеоролики на основі жіночих образів («Samsung», «Пантін»). $€$ підстави припускати, що на відміну від юнаків, дівчата більш довірливо ставляться до рекламної інформації (навіть у тому випадку, якщо вона не є для них емоційно привабливою).

На основі результатів первинної статистичної обробки даних (табл. 2) ми порівнювали описові статистики оцінки відеороликів респондентами. Як видно з таблиці 2, у всіх групах найбільш високі вибіркові середні величини (Mean) - це показники реклами «Банк Райфайзен» (Mean коливається від 94,9 балів у дівчат до 105,8 у хлопців), а найменші - це показники реклами «Хілак-форте» (найменші мінусові значення Mean у всіх групах).

3 метою визначення статистично значущих відмінностей в параметрах сприйняття рекламних відеороликів між досліджуваними групами ми використали t-критерий Стьюдента для незалежних вибірок (табл. 3). Виявлено п'ять статистично значущих відмінностей, які стосуються оцінки відеороликів «Отривін» (хлопці оцінюють його більш позитивно, ніж дівчата, $\mathrm{p} \leq 0,05)$, «Пантін» (дівчата оцінюють більш позитивно, ніж хлопці, при $\mathrm{p} \leq 0,001$ ), «Samsung» (дівчата оцінюють більш позитивно, ніж хлопці, при $\mathrm{p} \leq 0,05$; учні - більш позитивно, ніж студенти, $\mathrm{p} \leq 0,05)$ i «Банк Райфайзен» (хлопці оцінюють його більш позитивно, ніж дівчата, $\mathrm{p} \leq 0,05)$. 


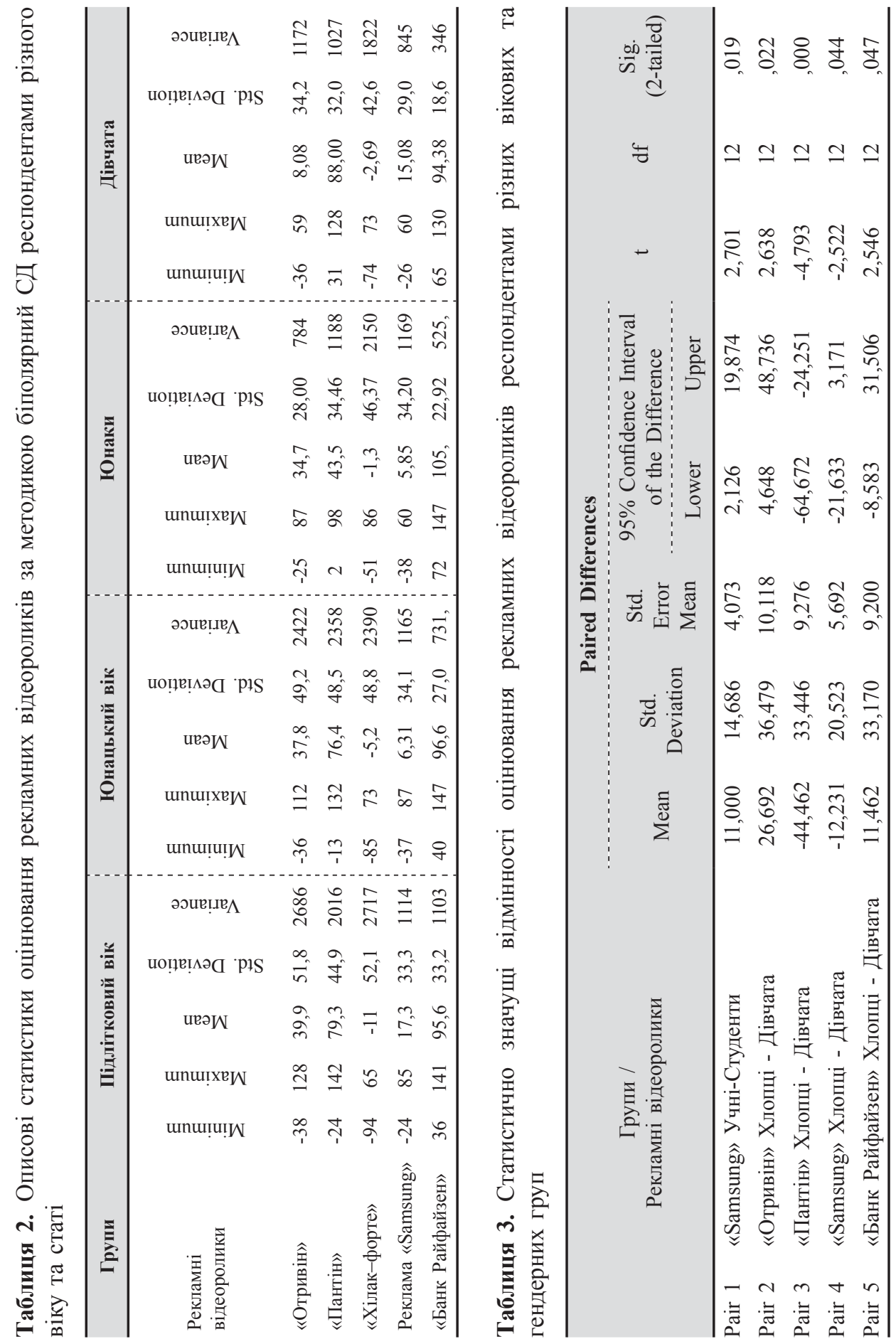


Отже, більшість значущих відмінностей пов'язана з гендерними аспектами сприймання реклами. Це, передусім, характерно для відеороликів «Пантін» та «Samsung», створених на основі жіночих образів, які мають за основу одвічну конфліктність чоловічого й жіночого начал як базових архетипів (Хавкіна, 2010: 131).

На останньому етапі дослідження ми здійснили більш детальну оцінку психосемантичного простору відеоролика «Банк Райфайзен», який отримав найвищі позитивні оцінки, тобто виявився найближчим до ідеального. За допомогою методу головних компонент після проведення процедури варимакс-обертання за критерієм Г. Кайзера було виділено 3 фактори 3 сумарною пояснюючою дисперсією $63,28 \%$ (табл. 4).

Таблиця 4. Факторна структура шкал семантичної оцінки рекламного відеоролика «Банк Райфайзен» до і після варімакс-обертання

\begin{tabular}{|c|c|c|c|c|c|c|c|}
\hline \multirow{3}{*}{ Характеристики СД } & \multicolumn{7}{|c|}{ ФАКТОРНІ НАВАНТАЖЕННЯ } \\
\hline & \multicolumn{3}{|c|}{$\begin{array}{c}\text { До VARYMAX } \\
\text { обертання } \\
\text { Фактори }\end{array}$} & \multirow[t]{2}{*}{$\begin{array}{c}\text { Значення } \\
\text { спіль- } \\
\text { ностей }\end{array}$} & \multicolumn{3}{|c|}{$\begin{array}{c}\text { Після VARYMAX } \\
\text { обертання } \\
\text { Фактори }\end{array}$} \\
\hline & 1 & 2 & 3 & & 1 & 2 & 3 \\
\hline Розслаблений - напружений & 0,172 & $-0,236$ & 0,655 & 0,61 & 0,817 & 0,128 & 0,108 \\
\hline Скромний - нав'язливий & & $-0,193$ & 0,736 & 0,54 & 0,739 & & 0,167 \\
\hline Зрозумілий - незрозумілий & 0,262 & & 0,443 & 0,49 & 0,372 & 0,625 & 0,327 \\
\hline Цікавий - нудний & & 0,205 & 0,573 & 0,43 & 0,651 & 0,142 & \\
\hline Радісний - сумний & 0,139 & & 0,633 & 0,64 & 0,487 & & 0,868 \\
\hline $\begin{array}{l}\text { Інформативний - } \\
\text { малоінформативний }\end{array}$ & $-0,217$ & $-0,224$ & 0,324 & 0,48 & 0,151 & 0,689 & 0,241 \\
\hline Швидкий - повільний & $-0,127$ & & 0,607 & 0,36 & 0,619 & $-0,154$ & 0,107 \\
\hline Оригінальний - банальний & & 0,768 & 0,124 & 0,78 & 0,109 & & 0,754 \\
\hline Розумний - нерозумний & 0,234 & 0,168 & 0,488 & 0,84 & 0,288 & 0,936 & 0,213 \\
\hline Неагресивний - агресивний & & 0,406 & 0,106 & 0,38 & & 0,167 & 0,619 \\
\hline Красивий - некрасивий & 0,795 & $-0,605$ & & 0,39 & & 0,131 & 0,563 \\
\hline Привабливий - відштовхуючий & 0,309 & $-0,107$ & 0,101 & 0,81 & $-0,123$ & & 0,912 \\
\hline Правдивий - неправдивий & 0,796 & 0,605 & & 0,97 & & 0,966 & 0,190 \\
\hline Доля дисперсії & 0,23 & 0,14 & 0,10 & 0,63 & 21,2 & 15,0 & 27,1 \\
\hline
\end{tabular}

Примітка. В таблиці вказані факторні навантаження, що перевищують за абсолютним значенням 0,1 . 
Третій фактор має найбільшу вагу (27,1\% дисперсіі) та інформативність. Він об'єднує 5 шкал, характеристики яких пов'язані 3 позитивними полюсами змінних: «привабливий відштовхуючий», «радісний - сумний», «оригінальний - банальний», «неагресивний - агресивний», «красивий - некрасивий». Отже, до цього фактора увійшли 3 найбільшою вагою такі прикметники як привабливий, радісний, оригінальний, красивий, оригінальний. Найбільша абсолютна величина факторного навантаження відмічена у змінних «привабливий - відштовхуючий» $(0,912)$ та «радісний сумний» $(0,868)$, тому позитивному полюсу цього фактора можна надати назву «Емоційна привабливість (непривабливість) реклами». Фактор певною мірою кореспондує 3 виділеним Ч. Осгудом фактором «Оцінка».

У другому факторі (21,1\% дисперсії) угрупувалося 4 шкали. Він визначається змінними «зрозумілий - незрозумілий», «інформативний - малоінформативний», «розумний - нерозумний», «правдивий - неправдивий». Найбільша абсолютна величина у останньої змінної (показник навантаження - 0,966), тому цей фактор можна визначити як «Довіра (недовіра) до реклами». На позитивному полюсі він характеризує рекламу як правдиву, інформативну та зрозумілу; на протилежному - як незрозумілу, брехливу, неінтелектуальну. Цей фактор певною мірою кореспондує 3 виділеним Г. Осгудом фактором «Сила».

До першого фактора (15,03\% дисперсії) увійшло 5 шкал. Він об'єднав такі семантичні ознаки як «розслаблений - напружений» (найбільша вага - 0,817), «скромний - нав'язливий», «цікавий нудний», «швидкий - повільний». Високі значення за цим фактором характеризують низьку енергетичну зарядженість та ненав'язливість об'єкту оцінювання, який водночас є цікавим. Найбільша абсолютна величина належить змінним «розслаблений - напружений» i «скромний - нав'язливий», тому цьому фактору можна присвоїти назву «Тактовність (нав'язливість) реклами». На позитивному полюсі він характеризує рекламу як розслаблену, скромну та цікаву; на протилежному - як нав'язливу, нудну, напружену. За отриманими семантичними ознаками він подібний до виділеного Г. Осгудом фактора «Активність» із зворотним значенням. Таким чином, в результаті факторного аналізу було виявлено три фактори («Емоційна привабливість (непривабливість) реклами», «Довіра 
(недовіра) до реклами» та «Тактовність (нав’язливість) реклами»), які складають структуру семантичного простору значень рекламного ролика «Банк Райфайзен».

На останньому етапі факторного аналізу була визначена міра впливу кожного 3 показників на загальну структуру оцінки відеоролика «Банк Райфайзен». Кількість всіх показників визначала розмір факторного простору - значення спільностей (табл. 3), який змістовно інтерпретується нами як «Психосемантична структура реклами «Банк Райфайзен». Зміст цього фактору визначається показниками, які мають найбільші факторні навантаження. Отже, за результатами аналізу фактор «Психосемантична структура реклами «Банк Райфайзен» визначається такими характеристиками СД як «правдивий - неправдивий» $(0,97)$, «розумний - нерозумний» $(0,84)$ (показники фактора «Довіра (недовіра) до реклами»); «привабливий відштовхуючий» $(0,81)$ (показник фактора «Емоційна привабливість (непривабливість) реклами»); «розслаблений - напружений» $(0,78)$ (показник фактора «Тактовність (нав'язливість) реклами»). В найменшій мірі цей показник залежить від показників «швидкий повільний» $(0,36)$, «неагресивний - агресивний» $(0,38)$ (рис. 5).

Таким чином, виділені нами показники статистично значуще можна вважати основними психосемантичними характеристиками, що визначають загальну оцінку, семантичний простір та емоційне сприйняття рекламного відеоролика «Банк Райфайзен».

Його успіх, з одного боку, може пояснюватися тим, що він побудований за принципом мікрофільму, де $\epsilon$ сюжет із зав'язкою, основною частиною та обов'язковою розв'язкою, 3 іншого - 3 його змістом, який $є$ емоційно привабливим, достатньо делікатним, ненав'язливим, таким, що викликає довіру та сприяє ідентифікації 3 його персонажами.

Отже, на основі отриманих результатів можна стверджувати, що найбільш ефективною та позитивно оцінюваною молоддю $€$ реклама, яка містить емоційно забарвлений «поведінковий» компонент (сюжет, ідея, актори та драматургія) та презентує товар як символ певного психологічного типу особистості, певного стилю життя та цінностей. Сюжет в найбільш популярних рекламних відеороликах («Банк Райфайзен» та «Пантін») цікавий респондентам, бо він не просто знайомить 3 товаром, але й пропонує історію $i$ цүінності, пов'язані з цим товаром. Можна погодитись із В.В. Зіркою 
(Зирка, 2004), що молодь купує не товар, а ті цінності та переваги, які він презентує (красу, мужність, надійність, привабливість, незалежність, волю, затишок тощо).

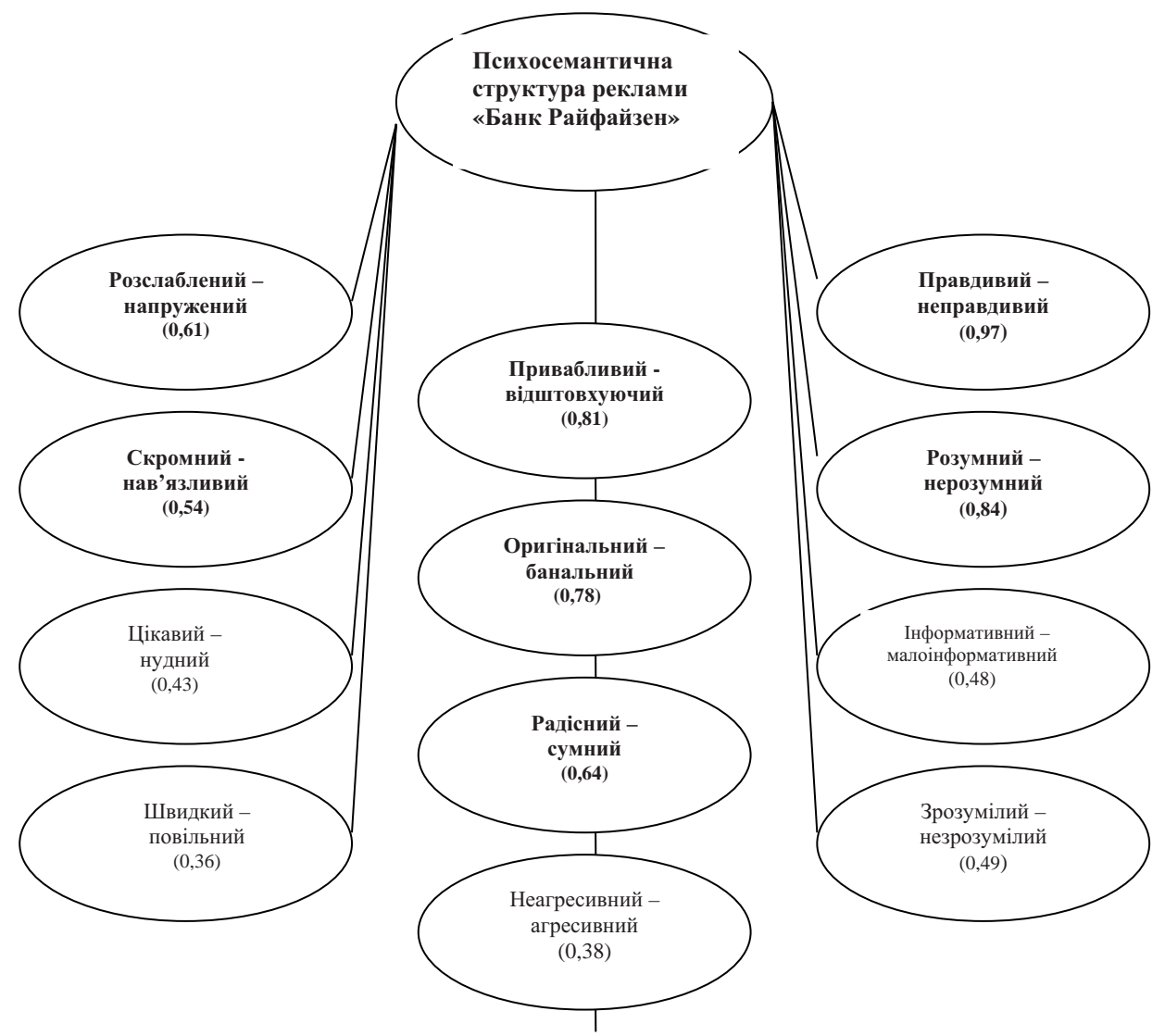

Рис. 5. Показники факторного простору (психосемантична структура) рекламного відеоролика «Банк Райфайзен»

Отримані емпіричні результати демонструють випадок впливу ціннісно-мотиваційної сфери на семантичну організацію значень в індивідуальній свідомості. Чим більш емоційною та особистісно значущою є зміст реклами, яка піддається усвідомленню, тим більше категоріальні структури індивідуальної свідомості потрапляють під вплив особистісних смислів. Тож, сприймання реклами у період дорослішання значною мірою опосередковане особистістю, iï імпліцитною теорією світу, себе та інших. 


\section{Висновки}

1. Реконструкція та порівняння семантичних просторів сприймання різних типів рекламних відеороликів респондентами підліткового та юнацького віку не виявили значних відмінностей. Якісний аналіз даних свідчить, що в період підліткового віку досліджувані більш позитивно оцінюють ігрові та музичні ролики, а в період юності відеоролики з використанням комп'ютерної графіки та спецефектів.

2. Значущі відмінності виявлено в семантичних особливостях сприйняття рекламних відеороликів юнаками та дівчатами (гендерний аспект). Так, юнаки більш позитивно сприймають рекламні ролики з використанням комп'ютерної графіки, а дівчата ігрові та музичні рекламні відеоролики з участю акторів, зокрема, жіночої статі. Дівчата в цілому більш довірливо ставляться до рекламних роликів, ніж хлопці.

3. Виявлено рекламні відеоролики, семантичний простір яких оцінено як більш привабливий у всіх вікових та гендерних групах. Це ігрові музичні рекламні відеоролики, відеоролики 3 участю акторів, наявністю сюжетної лінії та елементами драматургії («Банк Райфайзен», «Пантін»). Натомість, інформаційна реклама без сюжету та акторів (реклама «Хілак-форте») оцінюється негативно.

4. На основі факторного аналізу було виявлено складові факторного простору, які визначають психосемантичну структуру найбільш привабливого для молоді рекламного відеоролику (на прикладі відеоролика «Банк Райфайзен»): фактор «Довіра (недовіра) до реклами» (показники «правдивий - неправдивий», «інформативний - малоінформативний», «розумний - нерозумний»); фактор «Емоційна привабливість (непривабливість) реклами» (показники «привабливий - відштовхуючий», «радісний сумний»); фактор «Тактовність (нав'язливість) реклами» (показники «розслаблений - напружений», «скромний - нав'язливий», «цікавий - нудний»). Отже, емоційна привабливість відеоряду, довіра до його змісту, тактовність (ненав'язливість) його подачі $\epsilon$ тими висями, які відображують найбільш значущі психосемантичні аспекти сприймання молоддю рекламного відеоролика.

5. Більш привабливий образ у молоді формують ті рекламні відеоролики, які актуалізують позитивні та «ціннісно насичені» 
смисли торгової пропозиції, в яких акцент робиться не на власне споживчих якостях товару, а на символічних цінностях, що він презентує.

Проведене дослідження не вичерпує всіх аспектів означеної проблеми. Перспектива подальших розвідок полягає в експериментальному вивченні психосемантичних особливостей сприймання та оцінювання реклами в залежності від індивідуальнотипологічних, ціннісних та когнітивних характеристик споживачів реклами.

\section{Література}

Бахтин М.М. Эстетика словесного творчества. Москва: Искусство, 1979. 424 с.

Войтенко М.В. Прийоми маніпулювання у французьких рекламних текстах «Produits de luxe». Наукові записки Національного університету «Острозька академія». Серія «Філологічна». 2017. Вип. 67. С. 65-68.

Дедюхин А.А. Модели организации вербальной и визуальной информации в тексте рекламы (на материале английских и русских текстов рекламы автомобилей): автореф. дисс. ... канд. филол. наук: 10.02.19. Краснодар, 2006. 25 с.

Заболотна Т. Лексико-стилістичні особливості віртуальної реклами. Психолінгвістика. 2009. № 3. С. 196-202.

Залевская А.А. Интерфейсная теория значения слова: психолингвистический подход. London: IASHE, 2014. 180 c.

Зирка В.В. Манипулятивные игры в рекламе: лингвистический аспект. Днепропетровск: ДНУ, 2004. 294 с.

Корнилова Е.Е., Гордеев Ю.А. Слово и изображение в рекламе. Воронеж: Кварта, 2001. $224 \mathrm{c}$.

Лебедев-Любимов А.Н. Психология рекламы. СанктПетербург: Питер, 2003. 368 с.

Лившиц Т.Н. Специфика рекламы в прагматическом и лингвистическом аспектах: автореф. дисс. ... канд. филол. наук: 10.02.19. Таганрог, 1999. 20 с.

Музыкант В.Л. Реклама и PR-технологии в бизнесе, коммерции, политике. Москва: Армада-пресс, 2002. 688 с.

Осгуд Ч., Суси Дж., Танненбаум П. Приложение методики семантического дифференциала к исследованиям по эстетике и смежным проблемам. Семиотика и искусствометрия. Москва: Мир, 1972. С. 278-298.

Петренко В.Ф. Основы психосемантики. Санкт Петербург: Питер, 2005. 480 с.

Попова Е.С. Рекламный текст и проблемы манипуляции: автореф. дисс. ... канд. филол. наук: 10.02.19. Екатеринбург, 2005. 27 с.

Тарасов Е.Ф. Психолингвистические особенности языка рекламы. Психолингвистические проблемь массовой коммуникации. Москва: Наука, 1974. С. 80-96.

Шмелёв А.Г. Психодиагностика личностных черт. Санкт Петербург: Речь, 2002. 480 c.

Ученова В. Социальная реклама. Москва: ИНФРА-М, 2006. 275 с. 
Шмига Ю.І. Визначення реклами 3 погляду соціальних комунікацій. Вісник Київського нац. ун-ту. ім. Тараса Шевченка. Серія «Журналістика». 2014. Вип. 21. С. 29-30.

Шмига Ю.І. Ефективність телереклами в Україні (комунікативний аспект): автореф. дис. ... канд. філол. наук: 10.01.08. Київ, 2006. 26 с.

Хавкіна Л. Сучасний український рекламний міф. Харків: Харківське історикофілологічне товариство, 2010. 352 с.

Di Paolo, E.A., \& Thompson, E. (2014). The enactive approach. The Routledge Handbook of Embodied Cognition. London; New York: Routledge Press.

Erdogan, Z.B. (1999). Celebrity Endorsement: A Literature Review. Journal of Marketing Management, 15, 291-341. https://doi.org/10.1362/026725799784870379

Foolen, A. (2012). The relevance of emotion for language and linguistics. Moving ourselves, moving others. Amsterdam: John Benjamins. https://doi.org/10.1075/ceb.6

Greene, A.L., \& Adams-Price, C. (1990). Adolescents' secondary attachments to celebrity figures. Sex Roles, 23(7-8), 335-347. https://doi.org/10.1007/ BF00289224

Phua, J., Lin, J.S., \& Lim, D.J. (2018). Understanding Consumer Engagement with Celebrity-Endorsed E-Cigarette Advertising on Instagram. Computers in Human Behavior. Retrieved from https:/www.researchgate.net/publication/323311884 Understanding_Consumer_Engagement_with_Celebrity-Endorsed_ECigarette_ Advertising on Instagram $\overline{\mathrm{h}}$ ttps://doi.org/10.10 $\overline{1} 6 / \mathrm{j} . \mathrm{chb} .2018 .02 .031$

Osgood, Ch.E. (1984). Toward an abstract performance grammer. Talking minds: The study of language in cognitive science. Cambridge.

Osgood, C.E., Miron, M.S., \& May, W.H. (1975). Cross-cultural universals of affective meaning. Urbana: Univ. of Illinois press.

Panksepp, J. (2000). The neuro-evolutionary cusp between emotions and cognitions: implications for understanding consciousness and the emergence of unified mind science. Consciousness and Emotion, 1, 17-56. https://doi.org/10.1075/ce.1.1.04pan

Plichtová, J. (2002). Metódy sociálnej psychológie zblízka. Kvalitatívne a kvantitatívne skúmanie sociálnych reprezentácií. Bratislava, Média.

Sheets-Johnstone, M. (2012) Fundamental and inherently interrelated aspects of animation. Moving ourselves, moving others: Motion and emotion in intersubjectivity, consciousness and language. A. Foolen, U. Ludtke, T. Racine, \& J. Zlatev (Eds.). Amsterdam: John Benjamins.

Spalova, L., \& Bacikova, Z. (2017). Celebrities in social advertisement: psychosomatic perspective. Economic and Social Development: Book of Proceedings. Prague.

Trevarthen, C., \& Frank, B. (2012). Intuitive meaning: Supporting impulses for interpersonal life in the sociosphere of human knowledge, practice and language. Moving ourselves, moving others. A. Foolen, U. Ludtke, T. Racine, \& J. Zlatev (Eds.). Amsterdam: John Benjamins.

Urbánek, T. (2003). Psychosémantika. Psychosémantický př́stup ve výzkumu a diagnostice. 1. vyd. Brno: Psychologický ústav AV ČR a Nakladatelství Pavel Křepela.

Vorobyova, O.P. (2017). «Haunted by ambiguities» revisited: in search of a metamethod for literary text disambiguation. Lege artis. Language yesterday, today, tomorrow. The Journal of University of SS Cyril and Methodius in Trnava, 2(1), 428-496. https://doi.org/10.1515/lart-2017-0011

Zlatev, J. (2016). Turning back to experience. Cognitive Linguistics via phenomenology. Cognitive Linguistics, 27(4), 559-572. https://doi.org/10.1515/cog-2016-0057 


\section{References}

Bahtin, M.M. (1979). Jestetika slovesnogo tvorchestva [Aesthetics of verbal creativity]. Moscow: Iskusstvo [in Russian].

Vojtenko, M.V. (2017). Pryjomy manipuljuvannja u francuzkyh reklamnyh tekstah «Produits de luxe» [Methods of manipulation in French advertising texts]. Naukovi zapysky Nacionalnogo universytetu «Ostrozka akademija» - Scientific notes of the National University of Ostroh Academy, 67, 65-68 [in Ukrainian].

Dedjuhin, A.A. (2006). Modeli organizacii verbalnoj i vizualnoj informacii $v$ tekste reklamy (na materiale anglijskih i russkih tekstov reklamy avtomobilej) [Models of the organization of verbal and visual information in the text of advertising (on the material of English and Russian texts of car advertising)]. Extended abstract of candidate's thesis. Krasnodar [in Russian].

Zabolotna, T. (2009). Leksyko-stylistychni osoblyvosti virtualnoi reklamy [Lexicalstylistic features of virtual advertising]. Psyholingvistyka - Psycholinguistics, 3, 196-202 [in Ukrainian].

Zalevskaja, A.A. (2014). Interfejsnaja teorija znachenija slova: psiholingvisticheskij podhod [Interface theory of the word: a psycholinguistic approach]. London : IASHE [in Russian].

Zirka, V.V. (2004). Manipuljativnye igry $v$ reklame: lingvisticheskij aspekt [Manipulative games in advertising: the linguistic aspect]. Dnepropetrovsk: DNU [in Russian].

Kornilova, E.E., \& Gordeev, Ju.A. (2001). Slovo i izobrazhenie v reklame [Word and image in advertis]. Voronezh: Kvarta [in Russian].

Lebedev-Ljubimov, A.N. (2003). Psihologija reklamy [Advertising Psychology]. Saint Petersburg: Piter [in Russian].

Livshic, T.N. (1999). Specifika reklamy v pragmaticheskom i lingvisticheskom aspektah [The specifics of advertising in the pragmatic and linguistic aspects]. Extended abstract of candidate's thesis. Taganrog [in Russian].

Muzykant, V.L. (2002). Reklamni u PR-tehnologii v biznesi, komercii ta polityci [Advertising and PR-technologies in business, commerce and politics]. Moscow: Armada-press [in Russian].

Osgud, Ch., Susi, Dzh., \& Tannenbaum, P. (1972). Prilozhenie metodiki semanticheskogo differenciala $\mathrm{k}$ issledovanijam po jestetike $\mathrm{i}$ smezhnym problemam [Application of semantic differential techniques to research on aesthetics and related problems]. Semiotika i iskusstvometrija - Semiotics and artmetry, (pp. 278-298). Moscow: Mir [in Russian].

Petrenko, V.F. (2005). Osnovy psihosemantiki [Fundamentals of psychosemantics]. Saint Petersburg: Piter [in Russian].

Popova, E.S. (2005). Reklamnyj tekst i problemy manipuljacii [Promotional text and manipulation problems]. Extended abstract of candidate's thesis. Ekaterinburg [in Russian].

Tarasov, E.F. (1974). Psiholingvisticheskie osobennosti jazyka reklamy [Psycholinguistic features of the language of advertising]. Psiholingvisticheskie problemy massovoj kommunikacii - Psycholinguistic problems of mass communication, (pp. 80-96). Moscow: Nauka [in Russian].

Shmeljov, A.G. (2002). Psihodiagnostika lichnostnyh chert [Psychodiagnostics of personality traits]. Saint Petersburg: Rech [in Russian]. 
Uchenova, V. (2006). Socialnaja reklama [Social advertising]. Moscow: INFRA-M [in Russian].

Shmyga, Ju.I. (2014). Vyznachennja reklamy z pogljadu socialnyh komunikacij [Definition of advertising from the point of view of social communications]. Visnyk Kyivskogo nac. un-tu. im. Tarasa Shevchenka - Bulletin of the Taras Shevchenko National University of Kyiv, 21, 29-30 [in Ukrainian].

Shmyga, Ju.I. (2006). Efektyvnist telereklamy v Ukraini (komunikatyvnyj aspekt) [Effectiveness of TV advertising in Ukraine (communicative aspect)]. Extended abstract of candidate's thesis. Kyiv [in Ukrainian].

Havkina, L. (2010). Suchasnyj ukrainskyj reklamnyj mif [Modern Ukrainian advertising myth]. Harkiv: Harkivske istoryko-filologichne tovarystvo [in Ukrainian].

Di Paolo, E.A., \& Thompson, E. (2014). The enactive approach. The Routledge Handbook of Embodied Cognition. London; New York: Routledge Press.

Erdogan, Z.B. (1999). Celebrity Endorsement: A Literature Review. Journal of Marketing Management, 15, 291-341. https://doi.org/10.1362/026725799784870379

Foolen, A. (2012). The relevance of emotion for language and linguistics. Moving ourselves, moving others. Amsterdam: John Benjamins. https://doi.org/10.1075/ceb.6

Greene, A.L., \& Adams-Price, C. (1990). Adolescents' secondary attachments to celebrity figures. Sex Roles, 23(7-8), 335-347. https://doi.org/10.1007/ BF00289224

Phua, J., Lin, J.S., \& Lim, D.J. (2018). Understanding Consumer Engagement with Celebrity-Endorsed E-Cigarette Advertising on Instagram. Computers in Human Behavior. Retrieved from https://www.researchgate.net/publication/323311884 Understanding_Consumer_Engagement_with_Celebrity-Endorsed_ECigarette_ Advertising_on_Instagram $\overline{\mathrm{h}}$ ttps://doi.org/10.1016/j.chb.2018.02.031

Osgood, Ch.E. (1984). Toward an abstract performance grammer. Talking minds: The study of language in cognitive science. Cambridge.

Osgood, C.E., Miron, M.S., \& May, W.H. (1975). Cross-cultural universals of affective meaning. Urbana: Univ. of Illinois press.

Panksepp, J. (2000). The neuro-evolutionary cusp between emotions and cognitions: implications for understanding consciousness and the emergence of unified mind science. Consciousness and Emotion, 1, 17-56. https://doi.org/10.1075/ce.1.1.04pan

Plichtová, J. (2002). Metódy sociálnej psychológie zblízka. Kvalitatívne a kvantitatívne skúmanie sociálnych reprezentácií. Bratislava, Média.

Sheets-Johnstone, M. (2012) Fundamental and inherently interrelated aspects of animation. Moving ourselves, moving others: Motion and emotion in intersubjectivity, consciousness and language. A. Foolen, U. Ludtke, T. Racine, \& J. Zlatev (Eds.). Amsterdam: John Benjamins.

Spalova, L., \& Bacikova, Z. (2017). Celebrities in social advertisement: psychosomatic perspective. Economic and Social Development: Book of Proceedings. Prague.

Trevarthen, C., \& Frank, B. (2012). Intuitive meaning: Supporting impulses for interpersonal life in the sociosphere of human knowledge, practice and language. Moving ourselves, moving others. A. Foolen, U. Ludtke, T. Racine, \& J. Zlatev (Eds.). Amsterdam: John Benjamins.

Urbánek, T. (2003). Psychosémantika. Psychosémantický př́stup ve výzkumu a diagnostice. 1. vyd. Brno: Psychologický ústav AV ČR a Nakladatelství Pavel Křepela.

Vorobyova, O.P. (2017). «Haunted by ambiguities» revisited: in search of a metamethod for literary text disambiguation. Lege artis. Language yesterday, today, tomorrow. 
The Journal of University of SS Cyril and Methodius in Trnava, 2(1), 428-496. https://doi.org/10.1515/lart-2017-0011

Zlatev, J. (2016). Turning back to experience. Cognitive Linguistics via phenomenology.

Cognitive Linguistics, 27(4), 559-572. https://doi.org/10.1515/cog-2016-0057

\section{АНОТАЦІЯ}

У статті представлено результати дослідження психосемантичних особливостей сприйняття рекламних відеороликів в підлітковому та юнацькому віці (на прикладі учнів ліцею та студентів вищого навчального закладу України). Сучасна реклама розглядається як суспільний і сочіальнопсихологічний феномен, який моделює не тільки поведінку, а й цінності, норми, установки молодого покоління. Методологічною основою емпіричного дослідження стали наукові основи експериментальної психосемантики. Мета дослідження полягала в реконструкції семантичних просторів та індивідуальної системи значень, через призму якої відбувається сприйняття реклами підлітками та юнаками різної статі.

Психосемантичне дослідження здійснювалося в три етапи: шкалювання об'єктів реклами (на основі методу семантичного дифреренціала), побудова семантичних просторів рекламних відеороликів та інтерпретація отриманих результатів. В якості об'єктів оцінки обрано п'ять рекламних відеороликів різних типів (мультиплікаційний ролик "Отривін» 3 комп'ютерною графрікою і спецефектами; музичний ролик "Пантін» за участю акторів та з закадровим дикторським текстом; ролик інформаційного типу "Хілакфорте» з закадровим дикторським текстом; рекламний ролик "Samsung» 3 використанням знаменитості; сюжетний музичний ролик "Банк Райффрайзен» з акторами та з закадровим дикторським текстом). Здійснено порівняльний аналіз психосемантичних просторів цих об'єктів і визначено вікові і гендерні особливості їх сприйняття в підлітковому та юнацькому віці.

В якості основних смислових вісей психосемантичного сприйняття найбільш привабливого відеоролика (на прикладі відеоролика "Банк Райфрфайзен») виділено наступні фрактори: "Довіра (недовіру) до реклами» (показники СД «правдивий - неправдивий», «інформативний малоінформативний», "розумний - нерозумний»); «Емочійна привабливість (непривабливість) реклами» (показники СД «привабливий - відштовхуючий», «радісний - сумний»; «Тактовність (нав'язливість) реклами» (показники СД «розслаблений - напружений», "скромний - нав'язливий», «цікавий - нудний»).

Ключові слова: метод семантичного диференціала, психологія реклами, рекламний ролик, підлітковий вік, юнацький вік, відмінності. 
Шамне Анжелика, Доцевич Тамилия, Акимова Алина. Психосемантические особенности восприятия рекламных видеороликов

\section{АННОТАЦИЯ}

В статье представлены результаты исследования психосемантических особенностей восприятия рекламных видеороликов в подростковом и юношеском возрасте (на примере учащихся лищея и студентов высшего учебного заведения Украины). Современная реклама рассматривается как общественный и социально-психологический феномен, который моделирует не только поведение, но и ценности, нормы, установки молодого поколения. Методологической основой эмпирического исследования стали научные основы экспериментальной психосемантики. Цель исследования заключалась в реконструкции семантических пространств и индивидуальной системы значений, через призму которой происходит восприятие рекламы подростками и юношами разного пола.

Психосемантическое исследование осуществлялось в три этапа: шкалирование объектов рекламы (на основе метода семантического дирфреренциала), построение семантических пространств рекламных видеороликов и интерпретация полученных результатов. В качестве объектов оценки выбраны пять рекламных роликов разных типов (мультипликационный ролик "Отривин» с компьютерной графикой и спецэффректами; музыкальный ролик "Пантин» с участием актеров с закадровым дикторским текстом; ролик информационного типа "Хилак-фрорте» с закадровым дикторским текстом; рекламный ролик "Samsung" с использованием знаменитости; сюжетный музыкальный ролик «Банк Райфрфайзен» с актерами и закадровым дикторским текстом). Осуществлен сравнительный анализ психосемантических пространств этих объектов и определены возрастные и гендерные особенности их восприятия в подростковом и юношеском возрасте.

В качестве основных смысловых осей психосемантического восприятия наиболее привлекательного видеоролика (на примере видеоролика "Банк Райфрфайзен») выделено следующие фракторы: «Доверие (недоверие) к рекламе» (показатели СД «истинный - ложный», «информативный малоинформативный», "умный - глупый»); “Эмоциональная привлекательность (непривлекательность) рекламы» (показатели СД «привлекательный отталкивающий», "радостный - печальный», "Тактичность (навязчивость) рекламы» (показатели СД «расслабленный - напряженный», «скромный навязчивый», «интересный - скучный»).

Ключевые слова: метод семантического дифференциала, психология рекламы, рекламный ролик, подростковый возраст, юношеский возраст, различия. 